KAWISTARA

\title{
KONSEP PAKAIAN JOGJA FASHION WEEK CARNIVAL DALAM STRUKTUR SOSIAL DI YOGYAKARTA
}

\author{
Deni Setiawan \\ Fakultas Pedagogi Universitas Negeri Semarang \\ Email: denijusmani@gmail.com
}

\begin{abstract}
The Jogja Fashion Week Carnival (JFWC) is related to various agendas of the local government in Yogyakarta, particularly in industrial and tourism sectors. The JFWC event is correlated to the domestic industries in which one of them has a positive impact upon the progress and the existence of this industry in order to reduce the rate of import from outside Yogyakarta. In another domain, the use of public space, which is often done by JFWC event, gives entertainment and cultural education to the people, thus this event is useful and appropriate if it is held as a routine agenda for the existence of the tourism industry in Yogyakarta. The education given to the people includes the global warming issue, the treatment and utilization of hazardous waste, and the important role of JFWC event in an attempt to create clothing trend centre in Yogyakarta. The dialectics of JFWC clothes can be seen as a process of cultural diplomacy locally, nationally, and internationally. In addition, the existence of JFWC clothes can be viewed as a sustainability phenomenon of contemporary artworks in Indonesia.
\end{abstract}

Keywords: JFWC Clothes, Creative Industry, Contemporary.

\begin{abstract}
ABSTRAK
Penyelenggaran acara Jogja Fashion Week Carnival (JFWC) memiliki keterkaitan dengan berbagai macam agenda Pemerintah Daerah Yogyakarta, khususnya bidang industri dan pariwisata. Acara JFWC berkorelasi terhadap industri berbasis rumah tangga, yang salah satunya berdampak positif bagi kemajuan dan eksistensi industri, untuk menekan laju impor pakaian dari luar Yogyakarta. Pada ranah lain, pemanfaatan ruang publik yang sering dilakukan oleh acara JFWC, memberikan hiburan menyenangkan dan edukasi budaya bagi masyarakat, sehingga tepat jika acara ini menjadi agenda rutin bagi eksistensi industri pariwisata di Yogyakarta. Edukasi yang diberikan kepada masyarakat meliputi persoalan pemanasan global, pengolahan dan memanfaatkan limbah berbahaya, termasuk peran penting acara JFWC dalam usaha untuk menciptakan pusat tren pakaian di Yogyakarta. Dialektika pakaian JFWC dapat dilihat sebagai proses terjadinya diplomasi kebudayaan, baik lokal, nasional, maupun internasional. Selain, keberadaan pakaian JFWC dapat dilihat sebagai gejala keberlangsungan karya-karya seni rupa dengan sifat kontemporer di Indonesia.
\end{abstract}

Kata Kunci: Pakaian JFWC, Industri Kreatif, Kontemporer. 


\section{PENGANTAR}

Sejak tahun 2007, Yogyakarta menyelenggarakan karnaval pakaian, di kemas melalui acara Jogja Fashion Week Carnival (JFWC). JFWC merupakan bagian kegiatan Jogja Fashion Week (JFW), telah dilaksanakan sebanyak tujuh kali, sepanjang tahun 2007-2013. Kegiatan ini menghadirkan perancang pakaian, instansi pemerintah, sekolah, dan institusi pendidikan seni yang dapat memberikan bagi penyelenggaraan. Acara JFWC secara mendasar dilaksanakan untuk memberikan pendidikan budaya, pendidikan ekonomi kreatif, dan dalam upaya memajukan industri pakaian lokal.

Kemasan acara JFWC tidak terlepas dari upaya menghibur masyarakat, serta berperan serta untuk mengkampanyekan persoalan pemanasan global. Salah satu ciri khasnya adalah penggunaan bahan bekas dan pemanfaatan limbah (plastik, kertas, bambu) dalam pembuatan pakaian JFWC. Konsep pakaian karnaval yang di angkat bersumber pada cerita rakyat, kreasi imajinasi, dan tetap memperhatikan perkembangan tren-tren pakaian. Kegiatan JFWC terakhir dilaksanakan pada 18-22 Juni 2014, sebagai promosi dan kegiatan budaya, memajukan industri kreatif, dan bagian pertunjukan rakyat untuk pariwisata daerah.

Penyelenggaraan karnaval pakaian di Yogyakarta, selalu dinantikan oleh masyarakat. Selain sebagai sarana hiburan, kegiatan JWF dan JFWC merupakan sumber inspirasi bisnis bagi industri pakaian. Seperti pada JFW 2010 yang mengetengahkan pakaian-pakaian siap pakai, termasuk memodifikasi dan membuat kreasi kebaya. Terdapat persamaan dan perbedaan dalam menciptakan pakaian JFW dan JFWC karena memang memiliki konsep yang berbeda. Pakaian JFW lebih mengarah pada pakaian siap pakai, sedangkan pakaian JFWC lebih eksklusif, mengutamakan nilai seni, dan di produksi terbatas. Walaupun demikian, kreativitas perancang pakaian karnaval tetap memberikan peluang bagi industri pakaian untuk memperbarui jenis-jenis pakaian yang di jual.
Pakaian JFWC memiliki konsep dan karakter khusus, baik dalam hal tempat dan waktu pemakaian, bahan dan aksesori yang digunakan, termasuk karakter keindahan yang spesifik sebagai karya seni. Karakter karya seni tersebut, secara spesifik merujuk pada gaya-gaya seni rupa kontemporer, memiliki ciri paradigma estetik baru. Secara sederhana, paradigma estetik baru pada pakaian dapat dilihat pada perubahan konvensi pada pakaian JFWC, dari benda pakai menjadi benda hias/pamer. Akan tetapi, sebagai karya seni, pakaian JFWC tetap mengacu pada konvensi dan fungsi pakaian secara umum. Menurut Desmond Morris, ada tiga fungsi mendasar pada pakaian, yaitu memberikan kenyamanan, kesopanan, dan pameran (2002: 302).

Berdasarkan pada tiga fungsi pakaian menurut Morris, menghasilkan berbagai macam gaya pakaian. Gaya pakaian sangat bervariasi menurut geografi dan topografi, memiliki nilai denotatif dan konotatif, atau pun kode berpakaian pada situasi sosial (Marcel Danesi, 2004: 179-180). Gaya pakaian merupakan semacam kode berpakaian umum, yang menetapkan standar gaya menurut usia, jenis kelamin, dan kelas sosial (Danesi, 187). Demikian pula pada JFWC, memiliki standar-standar khusus yang disepakati dan ditetapkan oleh panitia penyelenggara, melalui konsep tertentu, selanjutnya membatasi konsep rancangan pakaian yang harus diikuti oleh seluruh peserta.

Harus diakui bahwa masih terdapat persoalan yang mengiringi pelaksanaan acara JFWC, khususnya JFW. Afif Syakur di tahun 2012 pernah menyebut bahwa penerimaan pengusaha yang bersumber pada ide-ide perancang pakaian JFW kurang dari sepuluh persen. Berdasarkan pengamatan Afif Syakur, terdapat beberapa permasalahan penting yang perlu segera diselesaikan. Permasalahan pertama adalah bahan baku untuk produk pakaian. Pengusaha pakaian lebih senang membeli produk tekstil dari luar Yogyakarta, karena lebih murah sebagai bahan produk massal. Permasalahan kedua, 
belum semua rancangan dapat diterima oleh pengusaha pakaian. Permasalahan ketiga, harga jual produk perancang pakaian JWF terlalu mahal, sehingga sulit untuk di beli oleh masyarakat ekonomi lemah (jogjanews. com).

Penelitian mengenai pakaian JFWC bertujuan untuk menguraikan konsep-konsep penciptaan pakaian dari sudut pandang sejarah seni dan estetika. Sejarah seni bertujuan untuk memperlihatkan perubahan dan perkembangan konsep acara dan pakaian JFWC dari tahun 2007-2013. Perubahan dan perkembangan konsep pakaian tersebut diuraikan kembali dari sudut pandang estetika, yang melihat persoalan karakter karya dalam seni rupa kontemporer. Tujuan penggunaan ilmu estetika adalah untuk melihat karakter-karakter baru yang muncul pada pakaian JFWC, akibat terjadinya pergeseran konvensi pakaian.

Landasan pikir buku The Fashion System, karangan Roland Barthes membicarakan panjang lebar mengenai dunia fashion dan mode, operasi struktur penanda mode, struktur penanda dan yang ditandai, serta struktur signifikansinya. Penelitian Roland Barthes menjadi salah satu dasar pijakan dalam kajian ini, bagaimana melihat persoalan seperangkat pakaian yang terhubung dengan relasi-relasi lainnya. Relasi lain, misalnya: konteks sosial, industri, budaya, dan konteks masyarakat. Hal yang terjadi pada pakaian JFWC, menunjukkan adanya ikatan relasi-relasi serupa, seperti: relasi kepada industri pakaian, pariwisata, budaya tradisi, dan masyarakat sosial (perancang dan komunitas).

Buku Art and Fashion: The Impact of Art on Fashion and Fashion on Art, karangan Alice Mackrell diterbitkan di London oleh BT Batsford pada tahun 2005, merupakan rujukan yang selanjutnya digunakan. Buku ini menuliskan persoalan antara seni dan mode. Mackrell membahas keberadaan dan tinjauan seni terhadap gaya-gaya pakaian yang sedang berkembang. Pendekatan yang digunakan adalah sejarah dan estetika, sehingga memberikan sumbangsih penting bagi penelitian pakaian JFWC, khususnya untuk melihat cara pandang penelitian yang dilakukan.

M. Agus Burhan menyampaikan, bahwa seni rupa kontemporer dapat di tinjau sebagai kecenderungan bentuk-bentuk seni rupa yang mengungkapkan berbagai konsep dan bentuk visual baru, atau di anggap sebagai karya seni dengan paradigma estetik baru (2006: 276-277). Paradigma estetik baru merupakan bentuk perkembangan yang terjadi dalam dunia seni rupa. Beberapa catatan lain, menunjukkan seni rupa kontemporer merupakan perlawanan terhadap seni rupa modern yang berlandaskan universalisme dan Barat, sedangkan kontemporer lebih mengedepankan nilai pluralisme (Jim Supangkat, et al, 2000: 22). Nilai pluralisme merupakan bukti akan konsep-konsep seni rupa yang cenderung menerima berbagai macam konsep penciptaan dan menghadirkan karya seni dalam wujud yang berbeda.

Pakaian JFWC merupakan pakaian yang sengaja diciptakan untuk dipamerkan, dengan terpaksa, nilai-nilai kegunaan pokok atau nilai mendasar pakaian akan diabaikan. Gejala semacam ini mirip, seperti yang di bahas oleh Mike Featherstone mengenai posmodern dalam bidang seni, yaitu penghapusan batas antara seni dan kehidupan sehari-hari, runtuhnya perbedaan hierarkis antara budaya tinggi dan budaya umum, suatu pencampuran stilistik yang mementingkan eklektisme (memilih yang terbaik) dan pencampuran berbagai aturan (2005: 155-173). Stilistik ini sifat tidak alamiah, melainkan memberikan nilai tambahan, menggayakan sesuatu, sehingga tampak lebih mewah dan indah. Pencampuran berbagai aturan atau konvensi berpakaian, dapat dibuktikan dan terjadi pada gaya pakaian karnaval, yang memiliki kecenderungan tampil secara mewah, glamor, dan plural.

Pelaksanaan acara JFWC dari tahun 2007-2013 diuraikan dalam sudut sejarah, yang memaparkan konsep penciptaan pakaian dari tahun ke tahun. Menurut 
Sartono Kartodidjo, sejarah dapat dibedakan dalam tiga jenis, yaitu: sejarah mentalitas, sejarah sosial, dan sejarah struktural (2002:5). Sejarah merupakan suatu dialog yang tiada akhir antara masa kini dan masa lalu, yang dapat dilihat berdasarkan kerangka keaneka ragaman, perubahan, dan kesinambungan melalui dimensi waktu (Kuntowijoyo, 2005:18). Pandangan Kartodirjo dan Kuntowijoyo mengenai sejarah digunakan dengan asumsi bahwa, terdapat persoalan struktur sejarah dan perubahan dalam dimensi waktu pada pakaian JFWC. Dimensi sejarah digunakan untuk melihat perkembangan dan perubahan pada konsepkonsep penciptaan pakaian JFWC.

Penelitian pakaian JFWC berjenis data kualitatif, dengan pendekatan dan analisis menggunakan teori sejarah seni dan estetika. Sumber data primer didapatkan melalui pengamatan langsung dari tahun 2009-2013, sedangkan tahun 2007-2008 didapatkan melalui sumber tertulis, termasuk menggunakan nara sumber.Pendekatan lainadalah metode kepustakaan, yang bersumber pada data cetak dan data elektronik. Data cetak bersumber pada majalah, tabloid, jurnal, dan koran, sedangkan data elektronik bersumber pada televisi, media massa elektronik yang diakses melalui internet. Nara sumber dan sumber data primer merupakan orangorang yang terlibat secara langsung pada JFWC, baik sebagai peserta, maupun sebagai penyelenggara. Data sekunder merujuk beberapa artikel pada media massa, termasuk foto hasil dokumentasi fotografer lepas, ataupun yang terikat pada penyelenggaraan.

\section{PEMBAHASAN \\ Pelaksanaan Jogja Fashion Week Carnival 2007-2013}

Pameran pakaian dalam acara Jogja Fashion Week Carnival, setiap tahunnya memiliki konsep yang berbeda-beda, alasan mendasar adalah untuk menghindari tematema yang berulang, menghindari kejenuhan, dan menghadirkan kreativitas baru, untuk memberikan inspirasi bagi pihak-pihak lain yang membutuhkan. Untuk itulah, Dinas
Pariwisata Daerah Istimewa Yogyakarta selalu mengganti pihak yang bertanggung jawab atas pelaksanaan acara JFWC, diharapkan selalu ada pemikiran baru. Pihak Dinas Pariwisata melakukan kerja sama dengan Asosiasi Perancang dan Pengusaha Mode Indonesia (APPMI) Yogyakarta dan mengundang ahli-ahli perancang pakaian, untuk mendapatkan hasil maksimal pada rancangan peragaan pakaian JFWC. Berikut ini adalah pelaksanaan JFWC dari tahun 2007-2013.

Acara JFWC di tahun pertama belum mempunyai konsep yang memadai, masih mencari bentuk, sistem pelaksanaan, dan hal teknis lainnya. Acara JFWC di tahun 2007 hampir secara keseluruhan mengikuti tema pada acara JFW. Perlu diketahui bahwa acara JFWC dan JFW masih satu rangkaian acara yang diprogramkan oleh Pemerintah Yogyakarta. Pada awalnya, acara karnaval pakaian ini merupakan bentuk peragaan dan pawai dari para pengusaha pakaian, dengan menggunakan 20 andong yang di hias. Setiap andong di isi dan menampilkan karya rancang pakaian dari seorang perancang pakaian. Beberapa karya yang dihadirkan, diantaranya karya Hamzah Batik dan Afif Syakur. Penggunaan andong, merupakan ide yang bersumber dari Hamzah Batik. Beberapa pihak lainnya yang terlibat adalah Lia Mustafa, Harian Umum Pikiran Rakyat, dan Paguyuban Warga Jawa Barat di Yogyakarta. Dinas Pariwisata Yogyakarta, merespon kegiatan karnaval tersebut, yang pada akhirnya dijadikan sebagai agenda tahunan, sebagai bentuk promosi industri pakaian, budaya nusantara, dan pertunjukan wisata.

Konsep Essentially Global di tahun 2007 merupakan upaya para perancang pakaian untuk mengetengahkan produk budaya masyarakat, yaitu kain batik, kain rajutan, dan kain tenun. Kain-kain tradisi tersebut di olah dan dipadukan dengan beberapa material lain, seperti: plastik, kain parasut, anyaman (bambu, daun pandan), dan kertas, di buat menjadi sebuah pakaian karnaval untuk menambahkan nilai jual. Konsep 
lain yang di angkat adalah identitas tradisi yang berkembang di nusantara, mengacu pada tokoh legenda, mitologi, dan cerita rakyat yang berkembang pada masyarakat Yogyakarta.

Tahun 2008, mengetengahkan konsep Culturally Plural, yang menampilkan kekayaan dan pakaian etnis bersumber dari kain tradisi (batik, tenun, dan rajut). Acara JFWC menampilkan beberapa bentuk pakaian karnval, diikuti dengan penampilan drum band, parade kesenian dari beberapa sekolah dan perguruan tinggi. Rombongan terdiri dari 15 kelompok pejalan kaki (kelompok kesenian atau sekolah/perguruan tinggi), 28 andong hias (peraga yang membawakan desain etnik dengan sifat fantasi dari salah seorang desainer), dan 100 sepeda ontel.

Beberapa peserta JFWC yang ikut berpartisipasi di antaranya adalah: Harpi Melati DPD Daerah Istimewa Yogyakarta, Tiara Kusuma, Bufa Model \& Taleny, Harpi Melati DPD Kota Yogyakarta, Ikatan Perangkai Bunga Indonesia, Puri Sekar Wangi, Yandz Salon, Widyawati Arta Moda, Akparda Yogyakarta, Samurai Pro, dan APIP'S Kerajinan Batik. Selain itu juga melibatkan Danar Studio, dan LPK Colours Modeling SMKN 4, SMA Kanisius, Akademi Manajemen Pariwisata Ambarukmo, termasuk Sanggar Seni dan Budaya Waria Yogyakarta. JFWC tahun 2008 memiliki rute perjalanan dari Keraton Ngayogyakarta Hadiningrat, Jalan Senopati, Jalan Gondomanan, Jalan Malioboro, dan berakhir di Keraton Ngayogyakarta Hadiningrat. Para peserta menempuh jarak sepanjang kurang lebih empat kilometer, pelaksanaan dimulai pukul 14.30-17.30 WIB.

Pelaksanaan ketiga, Boedaja in Motion merupakan acuan tema yang di pilih pada penyelenggaraan JFWC tahun 2009. Persoalan yang diketengahkan adalah mengenai eksistensi kain batik nusantara, yang tersebar di beberapa daerah di Indonesia, seperti: batik Pekalongan, batik Semarangan, batik Surakarta, batik Yogyakarta. Kain khas dari beberapa daerah tersebut di kemas menjadi bentuk pakaian fantasi, sebagai upaya untuk menghadirkan nilai-nilai tradisi pada pakaian modern. Acara ini melibatkan 30 andong hias dan 20 kelompok peserta karnaval.

Beberapa kelompok yang berperan di dalam acara JFWC 2009, di antaranya: Kelompok Sekolah Tinggi Pariwisata Ambarrukmo Jogja (StiPram) menampilkan beraneka ragam desain, mulai pakaian etnik warna cerah dengan membawa kipas dan topi kipas, punggawa kerajaan dengan pakaian serba hitam dan membawa tongkat, mengiringi sepasang pengantin yang di hias lukisan warna-warni. Selain itu, terdapat SMK Karya Rini Yogyakarta menampilkan pakaian dalam nuansa warna matahari sore, memakai corak batik coklat tua sebagai pakaian utama, ditambahkan selempang kain transparan oranye untuk mempertegas desain. Peserta dari SMK Negeri 6 Yogyakarta memainkan unsur bulu ayam warna-warni sebagai dominasi balutan pakaian, lengkap dengan topi ala gadis Meksiko, diiringi musik rebana.

Tahun 2010 mengetengahkan konsep Save Our Planet, berupa ajakan kepada masyarakat untuk lebih mencintai, menghargai, dan sayang terhadap bumi yang sudah tua. Kegiatan ini diharapkan mampu memberikan manfaat bagi keseimbangan dan keselamatan bumi, melalui usaha kecil dengan dampak yang besar, yaitu: menggunakan bahan limbah plastik sebagai bahan pakaian karnaval. Perlu diketahui, bahwa plastik ini merupakan limbah yang sangat berbahaya, dapat diuraikan oleh bumi dengan waktu 500 tahun. Jika tidak dikurangi dengan segera, sampah plastik akan mengganggu stabilitas dan keseimbangan ekosistem, serta berdampak buruk bagi kesehatan lingkungan. Oleh karena itu, plastik merupakan bahan utama yang digunakan pada JFWC tahun 2010.

Poin-poin kegiatan lain, berusaha untuk mengajak masyarakat penonton untuk mulai melaksanakan penanaman dan penghijauan bumi. Simbol-simbol kepedulian lingkungan dimunculkan pada karya rancangan pakaian karnaval, dengan warna-warna hijau sebagai wujud penghijauan pada bumi. Secara 
tampilan visual, peserta tetap menghadirkan pakaian dalam konsep-konsep tradisi, cerita rakyat dan legenda, selain ada tampilan yang bersumber pada bentuk-bentuk fantasi. Bentuk lain yang muncul adalah modifikasi bunga matahari, burung merak, dan kepala sapi. Keseluruhan peserta juga menggunakan kain batik yang dimodifikasi menjadi bentuk baju, selendang, topi, sayap, dan rok.

Pelaksanaan kelima, Sparkling in Vintage merupakan konsep pada acara JFWC tahun 2011. Peserta karnaval menampilkan pakaian karnaval dengan perpaduan batik sebagai sentuhan klasik dan tradisi. In Vintage berarti menghadirkan rancanan pakaian dengan kekuatan tradisi masa lalu, ditampilkan dalam garis rancangan populer. Bentukbentuk pakaian karnaval mengacu pada legenda dan cerita tradisi masyarakat, seperti: bentuk pakaian Nyi Roro Kidul, Ratu Ular, Nyi Blorong, Dewi Sri, Fantasi Mega Mendung, dan bentuk Abstrak (modifikasi api).

Tema Gempita Sukma Raya adalah yang diketengahkan JFWC tahun 2012, dilaksanakan pada sepanjang jalan Malioboro sampai Benteng Vredeburg. Beberapa tema yang direspon dan ditampilkan oleh peserta karnaval adalah Kebaya Kartini dan Cut Nyak Dien yang ditampilkan oleh Keluarga Besar Waria Yogyakarta dengan berkebaya serba merah. APIP's Kerajinan Batik menampilkan karya berjudul Shinta Obong, berupa sosok Rama Shinta yang diikuti oleh kelompok laki-laki berpakaian merah hitam dengan ide penciptaan api.

Panitia JFWC pada tahun 2013 mengangkat konsep Semarak Katulistiwa. Konsep ini dibagi menjadi beberapa subtema, yaitu Hamparan Laut di Katulistiwa (mengangkat cerita legenda dengan memasukkan unsur maritim), Gugusan Pulau di Katulistiwa (mengangkat cerita legenda dengan memasukkan unsur bangunan bersejarah), dan Ragam Budaya Katulistiwa (mengangkat cerita legenda dengan memasukkan unsur bentuk dan filosofi). Acara JFWC tahun 2013 mengusung konsep tematik beberapa diantaranya memakai pakaian dengan kisah legenda Dewi Lanjar dan Nyi Roro Kidul, cerita pewayangan yang ditampilkan dalam rangkaian pakaian penuh warna. Acara JFWC 2013 tidak hanya menampilkan pakaian gaya Jawa dan Yogyakarta, tetapi juga menampilkan kejayaan yang bersumber dari kebudayaan Kalimantan, Sulawesi, Sumatera, Bali, dan Papua.

\section{Peran-Peran JFWC: Diplomasi Kebudayaan, Pengembangan Ekonomi, dan Industri Kreatif Diplomasi Kebudayaan}

Pelaksanaan JFWC merupakan agenda tahunan yang dilaksanakan di sekitar musim liburan sekolah, musim libur kerja, sehingga dapat menarik wisatawan secara maksimal. Sebutlah JFWC 2014, yang dilaksanakan pada tanggal 18 Juni 2014, merupakan pembukaan dari serangkaian berbagai macam acara pertunjukan seni dan industri kreatif, seperti: pameran dagang produk tekstil, lomba cipta busana, peragaan busana, dan seminar tentang pakaian. Di sekitar tanggal 18 Juni 2014 tersebut merupakan awal liburan bagi sekolah dan beberapa instansi lain, dengan demikian, Yogyakarta sebagai salah satu kota tujuan wisata, telah menyiapkan serangkaian acara untuk menyambut wisatawan tersebut. Hadirnya penonton sebagai wisatawan yang berasal dari daerah Indonesia, termasuk wisatawan asing, menciptakan diplomasi kebudayaan.

Diplomasi dapat dilihat dalam bahasa yang sederhana sebagai suatu upaya untuk bernegosiasi. Negosiasi ini dapat dilakukan dengan berbagai cara, termasuk melalui upaya promosi, sebagai upaya untuk memperkenalkan pemikiran dan konsep dasar pakaian karnaval serta mempertemukan pemikiran pada perubahan fungsi pakaian secara umum, menjadi pakaian dengan sifat khusus. Di sini, terdapat beberapa kebudayaan yang akan dipertemukan dan diolah menjadi sehelai pakaian karnaval, sehingga sangat memungkinkan akan terjadi akulturasi kebudayaan, dan membentuk suatu pola budaya baru. Gagasan pikiran dan konsep pakaian karnaval yang di adobsi 
oleh peserta JFWC, setidaknya dapat di lacak sumber-sumbernya berdasarkan karakter dasar pada pakaian karnaval. Nilai-nilai baru dilihat sebagai hasil diplomasi dari berbagai macam kebudayaan, baik menyangkut cara berpakaian, fungsi pakaian, maupun dari aspek fisik (unsur-unsur desain).

Acara JFWC turut serta dalam promosi berbagai hasil kebudayaan Nusantara Indonesia, termasuk kebudayaan negara Jepang, yang dapat dilihat sebagai suatu diplomasi kebudayaan. Hal ini dapat dilihat pada konsep penciptaan dan bentuk (desain) pakaian karnaval yang ditampilkan pada JFWC dari tahun 2007-2013. Hal ini sangat sesuai dengan misi JFW sebagai upaya mendorong kreasi anak bangsa untuk menuju kualitas utama, memproduksi pakaian daerah dengan mengembangkan produk berbasis seni budaya tradisi. Potensi kekayaan budaya Indonesia pada ribuan pulau yang membentang di garis khatulistiwa merupakan penyangga kekuatan, sekaligus perekat dalam persatuan sebagai pijakan dalam membangun bangsa. Hasil produk pakaian harus terus dikembangkan dengan meningkatkan kuantitas dan kualitas dalam persaingan pasar.

Jika pada awalnya JFWC merupakan acara lokal dan tidak termasuk dalam agenda pariwisata, sangat berbeda dengan kondisi sekarang ini. Acara JFWC memiliki peran penting dalam agenda pariwasata produk seni rupa di Yogyakarta, termasuk promosi kebudayaan nusantara. Promosi produk hasil budaya merupakan bagian dari pengaplikasian beberapa jenis kain tradisi dari beberapa daerah di Indonesia pada pakaian JFWC, sehingga memberikan nilai jual tinggi sebagai bagian dari pengelolaan industri dan ekonomi kreatif. Salah satunya adalah penggunaan kain batik sebagai bahan pakaian karnaval, yang selalu digunakan oleh peserta JFWC dari tahun 2007-2013. Di tahun 2008, 2009, 2010, Dinas Pariwisata Kota Yogyakarta sebagai pihak pelaksana, memberikan bantuan kain batik Yogyakarta kepada setiap kelompok peserta JFWC, untuk bahan pakaian karnaval.
Adanya pengembangan tema JFWC di tahun 2011-2013, dan jangkauan wilayah, memberikan dampak positif penggunaan kain nusantara lainnya pada pakaian karnaval, yang memberikan ruang promosi kebudayaan nusantara semakin luas. Sebutlah kehadiran Tikar Serasan Kabupaten Natuna yang digarap oleh Lia Mustafa, Kain Tembe Bima yang dikerjakan oleh Danny Darmiansyah, Rumah Songket Adis yang mengerjakan dan mempromosikan kain songket Palembang, garapan kain dan ragam hias khas Aceh dalam Aceh Revival oleh Fitri Aulia, termasuk garapan Apip's Kerajinan Batik yang seringkali menampilkan batik kontemporer dan tradisional, tidak ketinggalan beberapa kain rajut, kain tenun, dan kain batik dari beberapa daerah lain.

JFWC di tahun 2013 misalnya, merupakan promosi besar-besaran hasil kebudayaan Indonesia kepada masyarakat. Dengan tema utama adalah "Semarak Warna Khatulistiwa" dengan sub tema, "Hamparan Laut Di Khatulistiwa", (menghadirkan cerita legenda dengan memasukkan unsur maritim), "Gugusan Pulau Di Khatulistiwa" (cerita legenda dengan memasukkan unsur bangunan bersejarah), dan "Ragam Budaya Khatulistiwa" (mengetengahkan cerita legenda dengan memasukkan unsur bentuk dan filosofi). Kegiatan tersebut, tidak saja menampilkan sejarah dan kejayaan pakaian dari Indonesia, termasuk mengetengahkan bentuk-bentuk bangunan dan penanda identitas dari daerah, seperti: ragam hias Dayak dari Kalimantan, gaya Asmat dari Papua.

Pada beberapa kali penyelenggaraan JFWC, seperti di tahun 2010-2014, dimunculkan gaya pakaian cosplay. Ciri khas dalam pakaian cosplay adalah memiliki rujukan dan tema-tema, yang mengacu pada karakter tokoh bersumber film animasi dan komik. Jika di Harajuku, Jepang, gaya cosplay merupakan wujud kecintaan para penggemarnya terhadap tokoh-tokoh kartun atau film animasi tertentu, yang divisualkan dalam busana dan aksesoris yang digunakan. Gaya Harajuku dalam wujud pakaian cosplay 
merupakan perpanjangan budaya Jepang, yang dikenal sebagai salah satu negara pencipta film animasi. Dukungan terhadap film-film animasi, sebagai wujud kecintaan terhadap produk anak negeri, ditunjukkan dalam pakaian cosplay. Sekaligus, dalam usaha mempromosikan dan mempengaruhi masyarakat dunia tentang keberadaan filmfilm animasi Jepang. Pengaruh ini saling terkait jejaknya dengan beberapa negara, seperti: Amerika, Singapura, Spanyol, Italia, dan termasuk di Indonesia. Jika mengamati perkembangan pakaian cosplay di Indonesia, wujud pertama kali yang muncul bersumber pada film animasi produksi Jepang, baru kemudian muncul karakter Marvel (termasuk Eropa), dan terakhir barulah karakter komik dan jagoan dari Indonesia.

\section{Pengembangan Ekonomi dan Industri Kreatif}

Berdasarkan Majalah Kina, diketahui kontribusi ekonomi kreatif dalam bidang ekspor pada periode 2000-2008 mencapai $9,2 \%$. Mengingat begitu besarnya kontribusi industri kreatif terhadap perekonomian nasional, pemerintah telah mengambil sejumlah kebijakan untuk mengembangkan industri kreatif di dalam negeri. Salah satu kebijakan yang diambil pemerintah adalah menetapkan subsektor industri mana saja yang dapat digolongkan sebagai industri kreatif. Setelah melalui studi intensif, akhirnya ditentukan 14 subsektor yang masuk dalam industri kreatif, yaitu: arsitektur, desain, fashion, film, video dan fotografi, kerajinan, layanan komputer dan piranti lunak, musik, pasar barang seni, penerbitan dan percetakan, periklanan, permainan interaktif, riset dan pengembangan, seni pertunjukan, televisi dan radio. Untuk memperkuat peranan dan lebih fokus, dikeluarkan Instruksi Presiden (Inpres) nomor 6 tahun 2009, tentang Pengembangan Ekonomi Kreatif. Disampaikan mengenai peran dan tanggung jawab dari instansi terkait dengan pengembangan ekonomi kreatif.

Direktur Ekonomi Kreatif Media Desain dan Iptek, Kementerian Pariwisata dan Ekonomi Kreatif, Poppy Safitri mengatakan, bahwa ekspor industri kreatif meningkat dengan rata-rata pertumbuhan $12,2 \%$. Pertumbuhan ekspor tersebut berasal dari industi pakaian dan kerajinan, dengan masing-masing kontribusi 60\% dan $36,5 \%$. Berdasarkan data, rata-rata kontribusi periode 2002-2010 mencapai $65,26 \%$. Pertumbuhan ini ditandai dengan banyaknya kegiatan kreatif, baik workshop, karnaval, festival, pameran, kompetisi, serta diskusi antarkomunitas. Kegiatan ini banyak dilakukan diberbagai provinsi di Indonesia, diantaranya: DKI Jakarta, Daerah Istimewa Yogyakarta, Jawa Barat, Bali, dan Jawa Tengah (neraca.co.id, 2014).

Industri pakaian di Indonesia tahun 2013 memberikan sumbangan sebesar Rp 181,6 triliun terhadap Produk Domestik Bruto (PDB). Jumlah tersebut menjadi kontributor kedua terbesar setelah kuliner untuk sektor ekonomi kreatif. Industri pakaian pada tahun 2013 tumbuh 6,4\% atau lebih tinggi dari pertumbuhan nasional $(5,7 \%)$ dan pertumbuhan industri kreatif secara keseluruhan (5,76\%). Dengan proyeksi pertumbuhan 6\%, diperkirakan oleh Mari Elka Pangestu, Menteri Pariwisata Ekonomi dan Kreatif, industri kreatif tahun ini akan menghasilkan senilai Rp 700 triliun. Sementara itu dari segi ekspor, nilai ekspor industri kreatif pada tahun 2013 mencapai US\$ 10 miliar atau sekitar Rp119 triliun, dengan laju pertumbuhan sebesar $8 \%$ atau dua kali lipat dari laju pertumbuhan ekspor total Indonesia (koran-sindo.com, 2014).

Target penyelenggaraan JFWC, seiring dengan maksud pelaksanaan JFW, yaitu: untuk mempresentasikan tren pakaian etnik, dengan berlandaskan pada pengembangan industri, termasuk menjalin relasi dan ikatan kerja industri pakaian berskala nasional atau internasional berbasis industri rumah tangga dan Usaha Kecil Menengah yang tersebar khususnya di Yogyakarta, umumnya di Indonesia. Kegiatan JFWC merupakan sarana promosi untuk mempresentasikan tren etnik sekaligus sebagai ikon budaya nasional, promosi industri pakaian, nama 
perancang pakaian, dan lembaga, untuk meningkatkan pengetahuan dan kecintaan masyarakat kepada budaya-budaya yang ada di nusantara Indonesia, sehingga diharapkan lebih bangga memakai produk dalam negeri. Dengan demikian, hasil dan dampak kegiatan ini dapat mendorong produsen lokal untuk membuat produk yang mampu bersaing dengan bangsa lain, dengan mengedepankan teknologi industri dan kualitas produk.

\section{Pakaian JFWC: Nilai Kontemporer dan Penonton \\ Nilai Kontemporer}

Menurut R.M. Soedarsono, konsep persoalan pakaian kontemporer sangat dekat dengan pemikiran Desmond Morris, yang sebetulnya fokus dalam produk-produk kemasan pameran atau pajang. Hal ini menunjukkan, bahwa terjadi perubahan fungsi pokok pada pakaian, beralih menjadi fungsi pamer atau lebih mengedepankan persoalan keindahan pakaian. Diuraikan lebih mendalam, pakaian sebagai benda pamer, tentu berbeda dengan pakaian kasual sebagaimana umumnya. Perbedaan tersebut tidak saja terletak pada tampilan secara visual, dapat juga dibedakan atas media atau material pembuat pakaian yang digunakan pada pakaian untuk dipamerkan.

Perbedaan ini akan tampak sekali ketika pakaian tersebut digunakan pada waktu dan tempat-tempat khusus, pakaian pamer cenderung memiliki ruang dan waktu yang terbatas. Perlu ditegaskan, pakaian pamer dapat dicontohkan dalam beberapa bentuk, seperti: pakaian karnaval, pakaian seni pertunjukan (tari, teater), pakaian cosplay, termasuk di dalamnya adalah pakaian dalam bentuk-bentuk fantasi. Pakaian pamer sebetulnya lebih akrab pada persoalan ekspresi dan luapan emosi seorang perancang pakaian, terkadang tidak terikat pada kebutuhan, konvensi berpakaian umum, ataupun persoalan pakaian sebagai bagian dari kehidupan sosial yang selalu terkait dengan norma-norma sosial, moral, dan etika.

Pakaian karnaval sebagai bagian produk seni rupa kontemporer berkembang dengan dinamis. Istilah kontemporer tidak berlaku untuk semua karya seni yang dihasilkan, dan juga tidak hanya berlaku untuk karya seni masa lalu, yang mungkin merupakan dikategorikan sebagai seni modern (Joan Gibbons, 2007:xiii). Seni kontemporer berada di zona yang bebas, terpisah dari hal-hal duniawi, fungsional karakter kehidupan sehari-hari, serta bebas aturan dan konvensi; didalamnya bersifat kebaruan (Julian Stallabrass, 2004:1). Bebas aturan dan konvensi dalam gaya pakaian karnaval, menunjukkan terjadinya kebebasan dalam penentuan karakter, bahan, warna, ragam hias, dan desain, sebagai bagian produk kontemporer. Seni rupa kontemporer dalam tinjauan waktu dapat berisi berbagai macam kecenderungan yang masih hidup dan tetap memperjuangkan eksistensinya. Hal itu dapat berbentuk dekoratif, pemandangan alam, abstrak, atau sampai pada bentukbentuk media seni yang baru.

Pakaian yang diterjemahkan dalam produk-produk kontemporer, memiliki sifatsifat paradigma estetik baru, membawa prinsip-prinsip kebaruan. Apa yang disajikan pada pakaian JFWC merupakan upaya mempertemukan nuansa tradisi (ide-ide mendasar) dengan karakter kontemporer dalam hal-hal gagasan teknik dan kebentukan yang bersentuhan dengan modernitas. Penanda kontemporer adalah terletak pada dihadirkannya nilai kedua pada pakaian, yang tidak lagi menjawab kebutuhan faktor fisik, melainkan dihadirkan sebagai produk-produk seni. Nilai-nilai kedua inilah memberikan ruang bebas pada bermainnya aksesori, hiasan, dan pernak-pernik pakaian sehingga yang terjadi kemudian dominannya kemewahan dan kepopuleran.

Jika memahami gaya pakaian dalam sudut pandang Agus Burhan, sebagai suatu karya seni yang memiliki paradigma estetik baru, akan sulit sekali diaplikasikan pada pakaian-pakaian kasual, yang lebih cenderung melakukan pengulangan bentuk dan desain. Sebut saja gaya retroyang populer pada tahun 1940, 1950, dan 1970, dengan desain sederhana dan warna-warna yang 
cenderung kontras, kembali dipopulerkan oleh beberapa perancang pakaian pada tahun 2012. Tidak saja di Indonesia, bahkan dipopulerkan oleh beberapa merk pakaian terkenal tingkat dunia, seperti: Prada, Valentino, Rochas, Louis Vuitton, dan Channel.

Berbeda jika paradigma estetik baru ini diaplikasikan pada pakaian JFWC, lebih menunjukkan karakter kontemporernya. Penanda paling jelas adalah konsep pikir, material, aksesori yang digunakan, kemasan pakaian, termasuk alih fungsi pada pakaian itu sendiri. Tentunya, secara sadar atau tidak disadari sama sekali, penggunaan kain batik yangdilakukandarigenerasikegenerasi, telah memberikan batasan jelas betapa terbatasnya gaya pakaian kasual. Persoalan estetika baru pada pakaian, jika diterjemahkan sebagai gaya yang serba sekarang ini, atau belum pernah ada sebelumnya, maka semakin menyempitkan ruang gerak kreativitas dan kekinian produk-produk pakaian.

Semakin tidak terbatas media yang digunakan, bentuk yang merepresentasikan kekinian, dan tidak ada perbedaan lagi terhadap ekslusif dan massif pada karya seni, merupakan karakter seni rupa kontemporer, seperti yang sebelumnya telah disampaikan oleh M. Agus Burhan. Jika mengacu pada Burhan, pakaian seni sebagai produk kontemporer diketemukan pada dua pemikiran, yaitu: memiliki referensi ganda atau bermacam-macam konsep penciptaan karya seni (pakaian karnaval) dan ungkapan seniman yang berbentuk presentasi. Seperti diketahui, pakaian karnaval hadir sebagai wujud dari beberepa referensi. Pada seperangkat pakaian JFWC, mengetengahkan kain tradisi nusantara, menghadirkan budaya tradisi dengan mengacu pada semangat cerita-cerita rakyat, mitologi, dan legenda, yang ditransformasikan ke dalam wujud pakaian. Pakaian tidak lagi sebagai bentuk representasi khazanah kekayaan masa lampau, tetapi lebih tepat dikatakan sebagai sebuah presentasi atas potensi-potensi yang dimiliki oleh masyarakat Indonesia. Produk yang dihasilkan dalam ranah seni rupa kontemporer memiliki kecenderungan karya seni dengan paradigma estetik baru. Perubahan yang terjadi dalam karya seni rupa, akan selalu terkait dengan sistem sosial, politik, ekonomi, dan budaya, pada masyarakat yang lebihluas. Paradigma estetik baru lebih dekat dengan isu posmodernisme dalam seni rupa (Burhan, 2006:277). Asumsi semacam ini berdasarkan adanya hubungan antara gaya pakaian dengan ciri-ciri yang melekat pada seni rupa posmodern.

Konsep kekinian dan bentuk baru dalam posmodern, seperti yang dibicarakan oleh Madan Sarup (2002:95-96) merupakan landasan pikir kekinian dalam konsep Burhan, yang dimaknai dan dilihat sebagai paradigma estetika baru, sehingga pakaian karnaval, tidak saja menjadi konsep berpakaian (perubahan fungsi pakai ke fungsi pamer) yang baru, tetapi menghadirkan gaya seni rupa baru. Perubahan fungsi pakaian, saling berafiliasi dengan penambahan makna-makna di dalamnya. Istilahnya Roland Barthes terjadi makna konotatif yang menyertai makna denotatif, sehingga yang terbentuk selanjutnya adalah citra-citra di masyarakat sosial dan penonton, termasuk pada kelompok perancang pakaian.

Perubahan fungsi, perubahan makna, dan perubahan material (gagasan penciptaan, bahan, aksesori) merupakan konsepkonsep kekinian itu sendiri. Tidak menutup kemungkinan, pakaian karnaval menjadi suatu konsep karya seni rupa seutuhnya, yang nantinya hanya dapat dinikmati secara menyeluruh dengan di tonton. Setidaknya, makna konotatif memberikan pemahaman lain bahwa pakaian bukan merupakan artefak mati (benda mati), tetapi memiliki makna lain yang saling berhubungan pada budaya, sosial, sejarah, ilmu pengetahuan, termasuk pula industri dan teknologi.

Agus Sachari dan Yan Yan Sunarya (2002: 163-164), dalam sudut pandang desain menyebutkan bahwa pemikiran posmodern sulit diterima oleh masyarakat Indonesia, dengan beberapa alasan. Pertama, kondisi masyarakat Indonesia belum dapat dikatakan sebagai masyarakat yang telah mencapai tahap "posmodern" dengan tingkat posindustri, 
lazimnya sebagai syarat infrastruktur sosial bagi kelahiran desain posmodernisme. Kedua, di Indonesia, perkembangan sejarah desain yang kompleks dari modernisme ke posmodernisme di Barat terjadi secara prematur, tidak pernah diikuti oleh gerakan pengkajian dan sikap penolakan yang jelas dalam menampilkan alternatif dengan sumber masyarakat sendiri. Adanya peniruan dan adobsi dengan sumber rujukan Barat.

Ketiga, inspirasi bentuk, warna dan ornamen, yang dijumpai dalam desain posmodern, terutama penganut Klasikisme Radikal merupakan hasil studi pada akar historis tradisi Barat. Keempat, salah satu tema utama posmodernisme adalah diakuinya aspek-aspek lokal-regional untuk diterapkan pada desain, dalam rangka menciptakan desain yang populis. Kenyataanya, di Indonesia menunjukkan bahwa desain baru, terlebih bangunan publik dan gaya pakaian dengan konsep posmodernisme, tetap diproduksi secara elit-birokratis oleh para pemilik. Hasilnya bukan bangunan atau gaya pakaian yang komunikatif, melainkan karya desain yang tergolong posmodernisme palsu, mencerminkan golongan dalam menampilkan citarasa.

Pelaksanaan JFWC tidak terlepas dari adanya Jogja Fashion Week, yang dimaksudkan untuk menciptakan acuan tren pakaian pada skala nasional, bahkan internasional. Beberapa konsep dan tema acara dihadirkan dalam nuansa kebarat-baratan, adalah bagaimana acara ini ingin dijadikan sebagai titik awal kebangkitan pakaian dengan konsep Indonesia (nusantara), dan menjadi rujukan skala nasional. Nilai-nilai kekinian pada pakaian JFW dan JFWC, tidak saja dalam bentuk dan desain, tetapi adanya perubahan fungsi pakai yang beralih menjadi bentuk pajang, adalah penanda penting sebagai produk kontemporer. Bahkan, pada tahuntahun 2006-2009, beberapa gaya pakaian yang dihadirkan dalam JFW mengacu pada konsep pajang, bukan konsep pakai. Secara khusus, karakter kontemporer ini hadir pada pakaian JFWC yang memang diciptakan untuk tujuan pameran pakaian.

\section{Penonton}

Pelaksanaan JFWC pada ruang publik, seharusnya tetap memperhatikan beberapa pertimbangan lain, seperti: pengguna jalan, kebebasan berekspresi, dan ikatan emosional antarpengguna ruang publik. Dengan demikian tidak mengabaikan persoalan beberapa kepentingan, seperti dibicarakan oleh Stephen Carr (1992:19), yang mengelompokkan tiga kualitas utama sebuah ruang publik, yaitu: responsive, ruang-ruang ini dirancang dan dikelola dengan mempertimbangkan kepentingan para penggunanya; democratic, hak-hak para pengguna ruang publik tersebut terlindungi, pengguna ruang publik bebas berekspresi dalam ruang tersebut, tetapi tetap memiliki batasan tertentu karena dalam penggunaan ruang bersama akan terdapat nilai-nilai toleransi diantara sesama pengguna ruang; meaningful, mencakupi adanya ikatan emosional antara ruang tersebut dengan kehidupan para pengguna.

Ruang publik dimiliki secara bersamasama oleh beberapa kelompok masyarakat, dengan berbagai macam kepentingan dan tujuan. Kepentingan sosial, kepentingan budaya, kepentingan seni, kepentingan politik, kepentingan ekonomi (komersial), ataupun kepentingan etnis sekalipun, dapat hadir secara bersama dan memiliki hak-hak terhadap pemanfaatan ruang publik. Setiap terjadi pertemuan kepentingan (interaksi, bisnis, dan pariwisata) dapat dilihat sebagai suatu proses sosial, yang timbul apabila sekelompok manusia dengan suatu kebudayaan dihadapkan pada unsur-unsur dari suatu kebudayaan asing, sehingga unsur-unsur asing itu lambat laun diterima dan diolah dalam kebudayaan sendiri, tanpa menyebabkan hilangnya kepribadian kebudayaan itu (Koentjaraningrat, 1996: 155).

Keberadaan penonton dalam pelaksanaan pakaian karnaval mempunyai kontribusi penting, di antaranya adalah sebagai apresiator yang menilai, sekaligus menentukan eksistensi pada tahun selanjutnya. Kehadiran penonton dianggap sebagai tolak ukur keberhasilan media dan 
iklan menjaring konsumen atau kelompok yang mencintai pakaian karnaval. Semakin banyak penonton yang hadir, maka semakin sukses dan berhasil suatu acara yang dilakukan. Pada acara JFWC terdapat dua macam penonton, dengan spesifikasi yang berbeda, yaitu: penonton aktif, orang yang memiliki tujuan dan sengaja hadir untuk menyaksikan acara JFWC, baik sebagai wisatawan, peneliti, ataupun untuk menikmati pertunjukan dan ramainya suasana kota Yogyakarta. Penonton pasif, orang-orang yang tidak sengaja hadir pada acara JFWC, seperti: pejalan kaki, pengguna jalan raya, dan pedagang.

Para penonton hadir pada satu jenis pertunjukan, untuk mendapatkan sesuatu hal yang tidak biasa, untuk mencari sesuatu yang baru (2013: 65). Menurut Lono Simatupang bahwa pembedaan dua kelompok sebagai penyelenggara dan sebagai penonton, merupakan pandangan yang menyesatkan karena mereka yang menyaksikan pameran merupakan tindakan atau aktivitas. Seharusnya, penonton ditempatkan sebagai partisipan peristiwa pameran pakaian sehingga akan dituntut peran dan keterlibatan penonton dalam menentukan keberhasilan atau kegagalan pameran sebagai sebuah peristiwa interaktif (Lono Simatupang, 2003:67-68).

Pada dunia pertunjukkan, penonton memiliki peran penting karena tanpa penonton, sebuah pertunjukkan tidak bermakna apa-apa. Oleh karena itu, penonton dikatakan sebagai kreator keempat, setelah penulis naskah, sutradara, dan para aktor (Gay McAuley, 2002: 238). Apa yang disebut oleh McAuley ini tidak berlebihan, dapat dibayangkan, jika sebuah karnaval atau pertunjukan pakaian lain, yang tidak dihadiri oleh penonton. Selain tidak terjadi "komunikasi", penampilan dan gemerlap panggung pertunjukkan pakaian akan menjadi sepi tanpa kehadiran para penonton. Beberapa pertunjukan, memberikan dan meletakkan penonton pada salah satu posisi yang penting, bahkan menjadikan ramainya penonton sebagai salah satu parameter berhasil atau tidak kegiatan yang dilaksanakan.

\section{SIMPULAN}

Jogja Fashion Week Carnival (JFWC) dilaksanakan dari tahun 2007-2014, dengan berbagai macam konsep. Kegiatan JFWC melibatkan desainer pakaian, instansi pemerintah, organisasi sosial, komunitas seni, dan institusi pendidikan seni. JFWC secara mendasar dilaksanakan untuk memberikan pendidikan budaya dan ekonomi keatif kepada masyarakat, selain untuk kepentingan pariwisata. Pakaian JFWC memiliki karakter khusus, baik desain, bentuk, tempat dan waktu pemakaian. Secara umum acara JFWC dimaksudkan untuk menciptakan pusat-pusat tren pakaian di Yogyakarta, khususnya menekan laju pakaian impor dan memasyarakatkan desainer pakaian kepada industri pakaian besar dalam skala nasional.

Acara JFWC pada awalnya berwujud peragaan satu jenis pakaian yang dikarnavalkan melalui andong hias, dengan jumlah peserta terbatas, melibatkan organisasi dan instansi yang terbatas. Beberapa tema yang muncul Essentially Global untuk mengetengahkan batik dipadukan dengan plastik, kain parasut, kertas, dan beberapa macam kain. Pelaksanaan masih fokus pada batik Yogyakarta. Cullturally Plural lebih luas menampilkan kekayaan dan pakaian dari beberapa suku di Indonesia. Peserta JFWC lebih bervariasi dari tahun 2007, dan mulai diberikan bantuan uang pembinaan kepada peserta. Boedaya in Motion dijadikan sebagai acuan tema JFWC, untuk menampilkan beberapa kain batik nusantara yang dikemas menjadi pakaian karnaval. Tahun 2010 fokus pada tema Save Our Planet, dengan isu utama adalah pemanasan global. Para peserta diharapkan fokus perancangan pakaian dengan memanfaatkan limbah bekas yang membahayakan lingkungan dan tanah, terutama plastik bekas. Tidak lupa dipadukan dengan batik Nusantara. Tahun 2011 fokus pada tema yang mengadobsi cerita rakyat, legenda, dan mitologi pada masyarakat daerah di nusantara, dengan 
acuan tema Sparkling in Vintage. Gempita Sukma Raya dan Semarak Katulistiwa merupakan tema JFWC tahun 2012 dan 2013, yang mengangkat pakaian daerah dan bangunan bersejarah dari beberapa provinsi di Indonesia.

Acara JFWC dan pameran pakaian karnaval merupakan agenda tahunan yang turut serta menyumbang wisatawan di Yogyakarta, termasuk di bidang industri pakaian. Gagasan pikir dan konsep pakaian JFWC merupakan wujud nyata terjadinya diplomasi kebudayaan, mulai dari cara berpakaian, fungsi dan aspek fisik pakaian. Pakaian JFWC merupakan wujud dari diplomasi kebudayaan, yang menunjukkan keindahan desain pakaian karnaval, nilai tradisi dari batik nusantara, sebagai wujud kekekayaan Indonesia. Tidak itu saja, pakaian JFWC juga menyajikan cerita rakyat, dongeng, legenda, dan bentuk bangunan pakaian dari beberapa daerah di nusantara. Selain di bidang budaya, agenda tahunan JFWC juga memberikan dampak positif bagi ekonomi dan industri kreatif. Dari tahun 20002010, dan di tahun 2013, sumbangan industri pakaian menyentuh angka Rp. 181,6 triliun, sumbangan terbesar kedua setelah bidang kuliner. Pertumbuhan industri pakaian mencapai nilai 6,4 \% di tingkat nasional. Hal ini sesuai dengan maksud pelaksanaan JFWC untuk mengeksiskan pakaian etnik, pakaian dengan landasan tradisi, sehingga dapat menjadi ikon kebudayaan nasional.

Pakaian JFWC memiliki ciri seni rupa kontemporer, yaitu dapat dikatakan sebagai seni rupa modern, bebas aturan dan konvensi, bersifat kebaruan, dan memiliki paradigma estetik baru. Paradigma estetik baru merupakan landasan pikir gaya seni rupa posmodern, yang bersifatkekinian, berbentuk baru, dan plural. Istilah kontemporer menunjukkan terjadinya perubahan fungsi pada pakaian, menjadi benda pamer atau benda pajang, mengutamakan keindahan daripada nilai kenyamanan berpakaian. Termasuk kebebasan dan kebaruan dalam mengaplikasikan berbagai macam jenis bahan pakaian. Kontemporer ini dapat pula dilihat dengan pemodernan nilai-nilai tradisional pada bahan pakaian yang digunakan. Acara JFWC dengan peragaan pakaian karnaval pada ruang publik dimaksudkan untuk menghilangkan batas-batas tinggi dan rendah antara penonton dengan karya seni, sarana komunikasi penonton dengan seniman, penonton dengan pihak industri pakaian, dalam kemasan pariwisata pada ruang publik.

\section{DAFTAR PUSTAKA}

Baderi, Firdaus. Ekspor Industri Kreatif Tumbuh 12,2\%. http://www.neraca. co.id/article/21451/Ekspor-IndustriKreatif-Tumbuh-122. 06 Mei 2014 (19.41).

Burhan, M. Agus. 2006. Seni Rupa Kontemporer Indonesia: Mempertimbangkan Tradisi. Dalam Jaringan Makna Tradisi hingga Kontemporer: Kenangan Purna Bakti untuk Prof. Soedarso Sp., M.A. BP ISI Yogyakarta. Yogyakarta.

Carr, Stephen, and Mark Francis, Leanne G. Rivlin, Andrew M. Stone. 1992. Public Space. Cambridge University Press. Cambridge University.

Danesi, Marcel. 2004. Messages, Signs, and Meanings: A Basic Textbook in Semiotics and Communication. Canadian Scholars' Press Inc. Toronto.

Gibbons, Joan. 2007. Contemporary Art and Memory: Images of Recollection and Remembrance. I.B.Tauris \& Co Ltd. New York.

Industri Fashion Sumbang Rp 181,6 Triliun. http://koran-sindo.com/node/369085. 06 Mei 2014 (20.03).

Kartodirdjo, Sartono. 2002. Teori Sejarah dan Masalah Historiografi. Dalam Dari Samudera Pasai ke Yogyakarta: Persembahan kepada Teuku Ibrahim Alfian. Yayasan Masyarakat Sejarawan Indonesia dan Sinergis Press. Jakarta. 
Koentjaraningrat. 1996. Pengantar Antropologi I. PT. Rineka Cipta. Jakarta.

Kuntowijoyo, 2005. Pengantar Ilmu Sejarah. Cetakan ke-5. Penerbit Bentang. Yogyakarta.

Majalah Kina: Media Ekuitas Produk Indonesia. 2011. Industri Kreatif Punya Potensi Besar Menopang Ekonomi Nasional. Edisi 3. 4-7. Jakarta.

McAuley, Gay. 2002. Space in Performance:Making Meaning in Theatre. The University of Michigan Press. Ann Arbor.

Mike Featherstone. 2005. Posmodernisme dan Budaya Konsumen. Pustaka Pelajar. Yogyakarta.

Morris, Desmond. 2002. Peoplewatching: The Desmond Morris Guide to Body Language. Vintage Books. London.

Mowforth, M. dan Ian Munt. 1998. Tourism and Sustainability: New Tourism in the Third World. Routledge. London.

Putri, Tri Artining. Pariwisata Sumbang Devisa US\$ 10 Miliar. http://wwww. tempo.co/read/news/2014/03/17/09056 2890/Pariwisata-Sumbang-Devisa-US10-Miliar. 06 Mei 2014 (14.10).
Sachari, Agus dan Yan Yan Sunarya. 2002. Sejarah dan Perkembangan Desain; dan Dunia Kesenirupaan di Indonesia. Penerbit ITB. Bandung.

Sarup, Madan. 2002. Identity, Culture and the Postmodern World. Edinburgh University Press Ltd. Edinburgh.

Simatupang, Lono. 2013. Pergelaran: Sebuah Mozaik Penelitian Seni-Budaya. Penerbit Jalasutra. Yogyakarta.

Soedarsono, R.M. 1999. Seni Pertunjukan Indonesia \& Pariwisata. Masyarakat Seni Pertunjukan Indonesia dan arti line. Bandung.

Stallabrass, Julian. 2004. Art Incorporated: The Story of Contemporary Art. Oxford University Press Inc. New York.

Supangkat, Jim, et al. 2000. Dimana Letak Yogyakarta Dalam Peta Seni Rupa Kontemporer Indonesia?: Sebuah Pengantar. Dalam Outlet: Yogya dalam Peta Seni Rupa Kontemporer Indonesia. Yayasan Cemeti. Yogyakarta.

Syakur, Afif. Launching Jogja Fashion Week 2012. http://jogjanews.com/afif-syakurbeberkan-kekurangan-dan-keinginangelaran-jogja-fashion-week. 15 Maret 2014 (11.01). 